\title{
Julia Kristeva: The Polylogic Wager (Part II)
}

\author{
Miglena Nikolchina
}

\section{Julia Kristeva: Le pari polylogique (2e partie)}

Dans la deuxième partie de son essai (la première partie se trouvant dans notre numéro précédent), Miglena Nikolchina s'intéresse au projet de Kristeva de théoriser la production du signe et du sujet. Kristeva parvient à la spacio-temporalité de cette production en rappellant la description de Freud de l'enfant comme étant déjà inscrit dans une texture du language et du fantasme, occupant "l'espace d'une compensation qui garde le père et son père distinct" (l'enfant est un remplacement pour le père du père et le porteur de sa culpabilité). L'enfant freudien est donc imaginé comme toujours inséré dans l'ordre symbolique. Toutefois, Kristeva trace un triangle différent dans lequel les deux autres parties sont la mère et sa mère: c'est dans cette "atopia" de la relation entre la mère et le corps de sa mère, suggère-t-elle, que le plus vieux drame du futur sujet parlant prend place. Cette fiction théorique permet à Kristeva de situer un type de relation entre les pulsions et la symbolique qu'elle nomme la libido féminine, " un espace amoureux approchable par n'importe quel sexe" mais qui a l'aspect de la récupération du corps de la mère de la mèreà travers l'acte de donner naissance. Cela a aussi l'aspect du cours répétitif de séparation avec sa propre mère: ce qu'une femme doit (undergo) subir lors de chaque expérience de naissance. De cette façon, la libido féminine est le lieu d'abjection et menace l'identité. D'après Kristeva, la reduplication ou la répétition obstruée est le langage de la libido féminine. Kristeva élaboreses idées sur la reduplication à travers une lecture des écrits de Marguerite Duras comme une sorte de discours clinique sans remède ou consolation, confiné à "dévoiler la maladie." Nikolchina dénote que l'allure d'une telle écriture de reduplication semble être aussi formidable pour Kristeva que pour les lectrices hypersensibles que Kristeva imagine se perdre dans l'écriture de Duras et demeurer désarmées par son affliction. Kristeva approche les écrivaines avec une distance analytique vigoureuse. Cependant, la critique faite à Kristeva à l'égard de sa valorisation des 
hommes écrivains ignore la fonction de la masculinité de ses écrivains dans son écriture: comme Nikolchina le suggère, ils engendrent Kristeva le sujet théorique qui les génère en recherchant ce qui la concerne. Une de ces choses qui la concernent est ce que Kristeva appelle le père imaginaire, une version de la mère perdue en un modèle de la possibilité de langage, le support pour une symbolique "moins sévère, plus attentionnée, tolérante, polylogique: maternelle?" Nikolchina termine en considérant les implications les plus profondes de l'insistance de Kristeva sur la signification comme étant le "parlé" de la pulsion vers la mort, un écho de la séparation de la cellule: la disparition ultime de la dualité maternelle/paternelle dans la séparation de la cellule nous rappelle que, sauf la différence sexuelle, "il y a aussi la différence problématique entre sexe et non-sexe." Comme "tous nos amours sont déjà dans l'ombre de la machine... est-ce que l'effort complet de l'écriture du corps est une façon d'être témoin de la disparition du corps?" "Est-ce que le labeur pour engendrer le langage équivaut à une requête pour la préservation absurde des différences sexuelles et de leurs problèmes dans un futur qui n'aura peut-être plus besoin d'elles?"

\section{The Epistemological Space}

The redoubling of the subject of Kristeva's stratified theoretical discourse answers the demand for a shift in the theoretical focus from the problem of the operations of the " $\mathrm{I}$ " to the problem of the process that produces this "I." "What we are asking is: How did this consciousness manage to posit itself? Our concern, therefore, is not the operating and producing consciousness, but rather the producible consciousness"

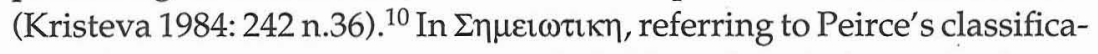
tion of science, Kristeva suggests a definition of semiotics as the theory that explores the time (chronotheory) and the topography (topotheory) of the signifying act(1969: 23) Hence one of the moves that inaugurate her project concerns a topotheoretical operation: the recognition of the epistemological space as split into two irreconcilable types of thought where "the one is articulated only through its ignorance of the other: representation and its production, the ratiocination of objects and the dialectic of their process (of their becoming)" (1977: 231).

This recognition of the epistemological space as split, always open and never saturated, comes, therefore, from the realization that the 
production of the sign and of the subject cannot be given within the homogeneous sphere of concepts and ideas, of formal logic as the logic of verbal expression or mathematics. ${ }^{11}$ In this homogeneous space, thought does not include its own creation. Frege's elaboration of the uselessness of logical negation is, for Kristeva, a compelling rendering of the dilemma that goes back to the Platonic vision of being and to the rejection, in Theaetetus and Sophist, of the existence of negative statements. Heterogeneity is purged from the realm of thought for which Plato and Frege stand: ${ }^{12}$ an inevitable operation, according to Kristeva, in so far as it corresponds to the thetic phase of the signifying process i.e. to the premises of the phenomenological subject. But it is only by approaching heterogeneity via concepts like Hegelian negativity, understood as trans-subjective and trans-symbolic movement, or the Freudian Ausstossung and Verwerfung, indicating the re-enactment of rejection, that we can accost the problem of the subject's and the sign's production, a production concealed by the thetic phase. Such a study requires another type of "logic" and a heterogenous economy: an epistemological space observable only through some discordance in the symbolic function.

The various indications of such a discordance and the knowledge about the producible consciousness that they provide are, therefore, at the centre of Kristeva's theoretical interest. From the examination of the permanently stabilized and destabilized interaction of the semiotic and the symbolic to the elaboration of the various modes of the subject's "leap" into the realm of signs, Kristeva's consistent aim is to demonstrate the dynamic character of the relationship between the symbolic and the heterogeneous economy that works it; to problematize the signifier as constantly unsettled and potentially susceptible to change. The thetic, i.e. the phenomenological positionality of the subject, adopted by Kristeva as the boundary between the symbolic and the semiotic and aligned with the positing of the imago, the mirror stage, and castration, is a traversable boundary: set in order to be challenged, established so that it can be shaken, this boundary differs both from an imaginary castration that has to be evaded in order to return to the semiotic chora (for the chora can be known only through the resumed rupture and the transgressed boundary) and from a castration imposed once and for all and fixing the signifier as "sacred and unalterable" (Kristeva 1984: 51, see also 1977: 57-58). ${ }^{13}$ One of Kristeva's persistent aims has been to explore the provisos revealing that the signifier is not sacred and that it 
is alterable.

It is, perhaps, worth repeating at this point that the question, for Kristeva, is not how consciousness in general came into being. It is how this consciousness came into being, i.e. a consciousness that is always regarded as a historically and geographically circumscribed problem. One of Kristeva's Marxian projects, as manifested in La Traversée des signes, is to find out whether different modes of production are bound up with different types of subject-formations and signifying practices. The project is left aside in her later work - in a simultaneous movement away from the Marxian and the non-Occidental problematic and towards an intensification of her focus on the micrology of the signifying process. Nevertheless, this unfinished project indicates that, for Kristeva, there are culturally and historically specific aspects to the signifying practice and to the making and unmaking of the subject at any observable point of this process.

This specificity implies that there are inevitable limitations to Kristeva's project - limitations not only in the sense of the accessibility of her "object" for theoretical positing but also in the sense of what can be expected from such a pursuit in any case. An example from Kristeva's early fascination with the East may prove helpful again. About Chinese Women is written partly as an answer to Freud's observation on the uniqueness of Chinese civilization in "admitting," through foot-binding, woman's castration. Kristeva notes that the insistence on underlining what is missing in woman by additional symbols reveals that "some doubt still persists" (1986: 83). Her hypothesis is that the excessiveness of the Confucian law was a response to an especially powerful tradition of "genitality," of an alternative economy allowing woman her own space, that had to be repressed.

The point is not to discuss the correctness of the hypothesis that the most severe cases of women's repression arose in response to women's greater power in the past. The point is to emphasize that, according to Kristeva, the variability of the law is bound up with a variable configuration of the "mystery." The discordance that she proposes to study, therefore, although offering a vertiginous glimpse of infinite splitting, provides a message that is contingent on the symbolic disrupted by it. Like Frege's realm where negation is always chimeric, the negativity revealed through analytic practice is located within its concrete setting and this setting is not without reference to Frege's negationless world. The space of production opening "behind" the space of the thetic function 
is thus not an exit into some sort of pure Schopenhauerean will or into a space of unlimited potentiality that can be subjected to any desirable refashioning. This space, on the contrary, is bound up with the signifying practices that order and articulate it. Music is Kristeva's case of pure semiosis but music is also one of the most obvious examples of the culturally specific enchainement ${ }^{14}$ of negativity. The study of the "revolution in poetic language" is framed, it should be remembered, by developments pertaining to French prosody. The examination of motherhood is inseparable from the forms that Western art and religion have bestowed on it. The loss of "psychic space" diagnosed in Tales of Love is a loss for the no longer tenable Occidental Christian "soul" with its Greek and Judaic lineage. And so on. Hence, in spite of Kristeva's insistence on the fake, the illusory and the ludic, one should not lose sight of the very concrete exigencies that summon them. "To every ego its object, to every superego its abject" (1982: 2). But also, to every symbolic its traversée.

\section{Time: the aiøu}

The enunciation of the disruptive space of the sign's and the subject's production necessitates a "chronotheoretical" operation: the elaboration of logical and chronological priorities, that is, the linearization of a synchronic functioning. It thus involves a specific mode of temporality, which Kristeva discusses in "Place Names" in terms of the emergence of the "child" in Freud's theory as the residue of the subtraction of guilt from mastery. This residue of the metamorphosis of the child into a parent is a telescoping of parent and child that presents us with a child "always already older," inscribed by "a narrative 'texture,' that is, a texture of language and phantasm" (1980: 276). Dictated by adult memory and articulated by the adult analyst, the child whose triangulated familial problematic serves to explain the production of the speaking subject, is inescapably that speaking subject's product: the speaking subject cannot be dealt with through a child at zero degree of symbolism or at the level of the drive. Hence any questions of priority and precedence have to be very carefully framed: the child - or, for that matter, the semiotic chora of which such questions are often asked - may be logically and chronologically prior to the adult (the symbolic), yet we have them always as an epistemological corollary.

This unsurmountable analytic circularity joining cause and effect is designated by Kristeva as an $\alpha i \omega 0$ on the basis of Heraclitus's 52d 


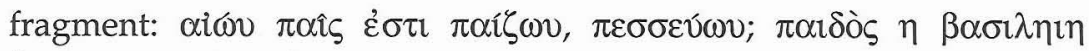
(Robinson 1987:36). Or, in G.S.Kirk's translation, "Aion is a child at play, playing draughts; the kingship is a child's" (Kirk 1954: xiii). As the translation itself suggests, through her designation Kristeva draws us, in fact, into another circularity, for the Heraclitean aion presents a classical hermeneutical problem: its meaning is undecidable within the context of this "most puzzling of Heraclitus's statements" (Robinson 1987: 116). Kirk limits the scope of options by including the fragment among the "anthropocentric" rather than the "cosmic" fragments: he thus makes a choice in favour of aion as "lifetime" rather than time in general. The child playing is hence not a cosmic child of some kind with a kingship over all things absolutely, but a figure referring to the working out of individual destiny. The decision is based on Kirk's interpretation of the rest of Heraclitus's fragments and depends on the uncertainties of this interpretation: one might hold the opposite view, as Robinson does. For once, therefore, we do not have to refer to Heidegger's penchant for speculative translation when he affirms that what is named in aion resists precisely the distinction that Kirk and Robinson make from two opposing perspectives. The aion, according to Heidegger, "means the whole of the world, but also time, and, related by time to our 'life,' it means the course of life itself" (Heidegger 1984: 77).

So is the aion eternity, time in general, lifetime, all this, or something altogether different? In the face of this uncertainty, what we are left with is the child playing and hence the idea of a pervasive ludic principle, a radical playfulness: whether the emphasis is on the game's rules, or on the arbitrariness of the rules; whether the child's royal power refers to cruel randomness and youthful irresponsibility (which is unlikely in view of the elevated status that Heraclitus bestows on children), or to some sort of Schiller-Kleistean antigravitational grace, is again indeterminate. In one case at least, however, the French translators Bollack and Wismann have decided to avoid the redundancy of the usual translations of Heraclitus's phrase ("a child at play, playing") and render the first "playing" $(\pi \alpha$ i $\omega v)$ through a mobilization of the etymological meaning that relates it to "child" ( $\pi \alpha \hat{\imath} \varsigma)$ : thus $\pi \alpha i \zeta \omega \vee$ becomes "making a child, engendering, giving birth." Do we have to point out that this etymological reinterpretation amounts to a backward translation into Greek of the French enfanter which has precisely the meanings that the translators ascribe to $\pi \alpha\{\zeta \omega v$ ? Do we have to add that the Greek phrase does not repeat the word for "play" and hence, perhaps, does not require 
measures for avoiding a redundancy that is far less obvious in it than in its translations? And do we have to complain that the translators ignore the kind of game that the child is playing, thus giving up its possible (but very problematic) implications? What matters for the time being is the aion that engenders, playing, the meaning of fragment 52. It is BollackWismann's translation that Kristeva refers to, and for good reasons, as we shall see.

What we read now is, "La vie est bien un enfant qui enfante, qui joue" (Bollack 1972: 182). In a superb final touch, the English translators Gora, Jardine and Roudiez render Bollack-Wismann's enfant as "newborn." The $\alpha i \omega$ ' (to go back to Kristeva's use of the term in the "silent" Greek alphabet) thus becomes "a newborn who bears, who plays" (Kristeva 1980: 292 n.9). Wonderful! For migrating from language to language, circulating through the aion of polyglottic engendering, what we have witnessed being born is the child of Kristeva's theory. Not the "always already older" child of the Freudian subtraction of guilt from mastery. In a truly aionic manner, fragment 52 as a "newborn who bears, who plays" gives birth to - is born from - the Kristevan child incorporating (1) Kristeva's emphasis on the pre-mirror and pre-oedipal stage as the semiotic site sustaining the sign's and the subject's making and unmaking; (2) Kristeva's problematization of birth as giving birth to the other, selfbirth, and rebirth; and (3) Kristeva's theoretical and, we might say, theatrical preoccupation with play and the drama of the " $\mathrm{I}$ " (the je of $j e u$ ) as masquerade, polyglottism, and "work-in-progress." The "infinite analysis" (of the subject of theory) that Kristeva's polylogue demands can now be described as the timespace - the aion - of giving birth to the child that bears its genetrix in a ludic renovation of meaning. The work/ play of rebirth: to a child belongs dominion.

\section{Female Libido}

Female libido is a Kristevan term that evolves out of Winnicott and Klein, that is subtended (like most things in Kristeva) by the death drive, and that designates a specific type of correlation between drives and the symbolic. Like Freud's male libido which is common to men and women and informs any erotic relationship, the female libido is not applicable to only certain groups of people, but is an amorous space approachable from any gender position. Male libido and female libido pertain to a typology of loves and not to a typology of bodies. What Kristeva 
accentuates, however, is that female libido is not, strictly speaking, a libido, that it cannot replace the dialectic of Eros (its tendency being towards fusion rather than dialectic), and that its powers and applications, mobilized by the metaphoric leap of Einfühlung ${ }^{15}$ rather than the metonymic flight of desire, are not in the sphere of sexuality but, indeed, elsewhere. In love.

Why, then, is this quasilibido termed "female?" If the Freudian child springs from the death of the father's father - "the father is dead, long live the father that $I \mathrm{am}^{\prime}$ - and if this child, "born into the world with compound drives, erogenous zones, and even genital desires" (Kristeva 1980: 275), acquires its form within the oedipal triangle, the Kristevan pre-oedipal infant emerges (theoretically, but also biographically as in Freud's case?) in the recovery of the body of the mother's mother through the act of giving birth. This gloss on the Freudian equation of the child to a penis-substitute (since giving birth gives an access for the daughter to the body of her mother) situates the newborn in an unusual triangle where the other two parties are the mother and her mother. A precarious triangle, formed by the amplification of the mother-child dyad. The female libido, therefore, is the space or no-space in which a mother attains the infinite body of her death-proof mother. "The mother lives, long live the mother that I am." It is in this "atopia," traced by Kristeva with reference to Winnicott's "potential space," that the earliest dramas of the future speaking being take place.

In this triangle, unlike the oedipal triangle informed by the male libido that is tied to an object, the forces of attraction are objectless. The pre-oedipal atopia is thus marked by a tendency towards equalization in which "alterity becomes nuance, contradiction becomes a variant, tension becomes passage, and discharge becomes peace" (1980: 240). Inscribed within the site of the smallest and most uncertain of differences, the "analysis" through which the infant both reunites and precludes the symbiotic fusion of the mother and her mother wields enormous powers but also poses great risks. For if, on the one hand, this is the "not yet a place" in which woman adjoins her first love object that had to be replaced through the oedipal exigences, the reunion has the aspect of a total erotization, an erotization without residue, that permeates the universe with an amorous glow and ushers in mystic and ecstatic merging, the Schopenhauerean relinquishment of will, the Oriental Nothingness. In its measureless radiance, the female libido is the fons amoris behind the histories of our loves (rather than sexuality), the narcis 
choly, of the unaccomplished separation from the maternal Thing, that is carried out in the Black Sun. Duras's writing, indifferent to the modernist concerns with the music of speech or with the dismantling of narrative logic, is described as offering an "aesthetics of awkwardness" and a literature without catharsis (1989: 225). Her sentences are seen as lacking acoustic charm and her books are perceived as dangerous for the oversensitive reader who might give in to their spell and remain arrested by the affliction that they recognize but also propagate: these books do not offer the consolations of rhetoric, the purging cure of artifice, or the festive animation that even everyday speech possesses. Duras's use of language reveals an underrating of language, an awareness of its powerlessness. Language thus almost gives way, it is pushed aside for a confrontation with nothingness and the silence of horror. Devoid of catharsis, of purification or forgiveness, Duras's writing remains "on the near side of any warping of meaning, confining itself to baring the malady" (1989: 229).

A literature without literariness, an art without artifice, a horror without sublimity? But also a historicity outside of time, a politics outside of the public realm: in the spectrum of private suffering. It is true that all portraits of melancholy artists in the Black Sun share a transhistoric quality that pertains to the timeless and atopical space of unaccomplished separation from the mother. It is also true that in all these cases the private suffering of the artist is interwoven with a historical crisis that is hence uncovered: Holbein and the crisis of the Christian subject during the Reformation, Nerval and the crisis of values in the nineteenth century, Dostoevsky and the pending Russian revolution, Duras and the apocalyptic dimension of our own times. In all these cases, however, with the exception of Duras, the artists also offer a solution: Holbein creates beauty out of deadness, Nerval extracts an Orphic victory out of madness, and Dostoevsky evolves forgiveness out of the destructive allures of suicide and terrorism. Duras is the one who offers nothing but a stark confrontation with distress and pain. Instead of a solution, Duras presents "a world of unsettling, infectious ill-being" (1989: 258). The work of Holbein, Nerval, and Dostoevsky is triggered by a timeless private suffering but it offers its solution to an epoch; the affliction in Duras's fiction is triggered and increased by the insanity of the contemporary world but it nevertheless "proves to be essential and transhistorical" (1989: 258). Outside of time.

There is a paradox involved in this situation: for it is precisely Duras's ahistorical quality that makes her historically representative for our 
epoch, rendered speechless by apocalyptic suffering; it is the absorption of politics by the personal that epitomizes the modern political choice; and it is out of Duras's resistance to meaning that Kristeva weaves the meaning of the contemporary world. The paradox itself, however, cannot conceal another movement in which Duras's writing is held captive. For in its ahistoricity and awkward a-literariness, in its closeness to clinical discourse without the cure, Duras's work of reduplication joins and enhances the narratives of Kristeva's own female patients and thus speaks the very timeless and atopical realm that Kristeva's study approaches: the realm of female libido, of the passion for the mother, of the murderous-and-suicidal drive for totality and fusion.

Are we offered, then, a theoretical variant of reduplication, of the hypnotic gaze? Does Duras become encrypted in the crypt that Kristeva's analysis delineates? While Kristeva's artists, male or female, more often than not function as the doubles of her theoretical endeavour, the case with Duras, stripped of historical or aesthetic dimensions in order to reveal the very source of redoubling, of enthralled hatred and spellbinding passion, seems to be especially striking. Is it because "as an echo to death-bearing symbiosis with the mothers, passion between two women represents one of the most intense images of doubling" (Kristeva 1989: 250)?

How does fear of the maternal body become fear of another woman's word? Why does Kristeva in her inquiry into hainamoration, the lovehate that marks our passions, never refer to the written beginnings of the Occidental language of passion and to the earliest articulation of lovehate: to the celebrated inscription, provided by Sappho, of the "Ilove and I hate" of desire, of the "two souls" of the lover? Why is the only nonanonymous woman's "tale of love" a tale of the "perfection of silence"? ?16 Why is Duras's writing beyond language and temporality? While the balancing perspective is always there (witness the counterpoint that the discussion of Clarice Lispector provides to the discussion of Duras on pages 228-9, as well as the reference to different, "neoromantic" trends in Duras herself on page 230), Kristeva's cautious and infrequent approach to women's writing ${ }^{17}$ invariably addresses the risks of reduplication, its delights and its lethal attractions. These risks deserve scrutiny for they have left their tangible trace in the tendency of the "woman reading woman" to waver between abjective criticism (where the author, instead of being read, is "incorpsed" and thrown out of the 
"proper body" of literature) and fusional reading (where no distance is allowed between the critic and her author). Kristeva avoids such extremes. Like Thomas Mann who chose to write about Dostoevsky (i.e. about extremism and excess) "with measure," Kristeva's approach to women-artists emphasizes the demand for a lucidity, a knowledgableness, that writes about hypnotic passion - from an analytic distance.

\section{Intersexuality}

There is a child, consequently, the perennial child that the artist is, mediating Kristeva's discourse on the maternal problematic: marking the turbulent border between a mother and her mother. Kristeva's artists share, in fact, a number of characteristics that make them strangely similar. They all are obsessed with the great maternal passion and many of them adopt their mother's (grandmother's, in Céline's case) name or esoterically play with it as in Lautréamont's phonetic and graphic transpositions (Kristeva 1974: 327). For them, in one way or another, the signifying practice is a happily accomplished incest and opens up an excess of meaning as in the chromatic translucency of Bellini's painting or the stellar laughter of Dante's Paradiso, but it may also unfold the horror of collapsing boundaries and thus drive into a creativity accomplished as incessant flight. The artistic practice studied by Kristeva thus amounts to the "appropriation - mysterious or violent, fetishist or psychotic - of this reverse side, the support and source of power, that is the mother's strength and jouissance" (1974: 483). Hence Kristeva's artists tend to usurp the feminine role and find their double in a sister-figure that duplicates their own experience of what is exterior to the symbolic and their problematic invocation to the outside of meaning.

A "vertical couple" is thus formed which, through the genderization of alterity, dramatizes the Signifier-Signified couple as a dynamic relationship in which positions can be shifted and the artist can assume any of them, male or female, maternal or paternal, turning the text into the space where sexual differentiation is effected. It is male artists mirrored by their silent "sisters" that Kristeva's theory approaches. The artists become "brothers" mirroring her theoretical endeavour. It would be thus equally precise to say that there is a woman (the mother) behind Kristeva's artists who provide the bridge for the theoretician's quest (i.e. the artists are guides towards the mother); or, that there is a man (an artist) between the woman-theoretician and the mother that she seeks to 
recuperate - there is an in-between, a brother-and-lover who, through the offering of an erotic investment in an other, diverts the theoretician's movement from the fascination of her silent and hidden object towards writing. Within the region of collapsing identities, which Kristeva's work explores, the maleness of the artist is the guarantee, always uncertain, of the constantly challenged conditions of alterity. The artist thus has the go-between function to unite by separating or to separate by uniting. As both a superconductor and an insulator, he ensures the dialectic of Kristeva's quest.

The critique of Kristeva's privileging of male artists, therefore, ignores the significance that the maleness of Kristeva's artists has in her writing. The very similarity between her protagonists reveals that they are aionic children and that, playing, they engender the theoretical subject generating them in search of matters of her own concern. The couple artist-silent sister is hence reproduced as theoretician-brother artist in an incestuous embrace that "mixes body and thought in one and the same trace" (Kristeva 1977:8) and invariably gives birth to its strange offspring - a presence in meaning as that meaning's outside.

\section{Ludic Discipline}

The contrary movement, the movement that reverses the quest of the theoretician and draws a trajectory from the limits of the thinkable, from the site of primary repression, to the register of the symbolic - can be achieved through a shortcut that Kristeva terms "primary identification." Primary identification effects a direct transfer to an ideal other, to a unifying object that serves as a constitutive metaphor of the subject. In so far as this identification, which precedes Oedipus, amounts to the incorporation of a scheme, a model, of the very possibility for language, for distinction and differentiation, the object is a "non-object" and the amorous transference (meta-phor) that it involves is, strictly speaking, objectless. It is accomplished as fusion, communion, unification. It is thus an instantaneous - but involving a transposition into a heterogeneous register - translation of the female libido into love, "Agape."

This archaic pole of idealization that is a father-mother conglomerate and that combines the attributes of both parents is developed by Kristeva out of Freud's "father of individual prehistory" and out of Klein's conception of "projective identification" and of the gratitude directed at the maternal object in its totality. Kristeva names this instance 
"imaginary father." As a heterogeneous translation, as a transposition that metaphorically relays the subject via an immediate leap to the place of the mother's desire, this idealizing movement that originates in the most archaic of settings and transforms the lost mother into an imaginary father can be regarded as the Urform of intertextuality. The result is a living and loving father, not the dead phallus of Osiris that the sterner versions of the symbolic exhibit. The imaginary father is hence a "paradoxical concept that operates within two very different conceptual networks: those of Lacanian transference and Hegelian dialectic. In other words, because it allows synthesis as a heuristic fiction to emerge from the relationship of transference, it also makes the symbolic the site of the imagination" (Rajan 1992: 33).

Is, therefore, the role of the imaginary father - in a manner similar to the phallic mother's role as the uncompromising support of the relentless paternal Law - to support a symbolic less severe, more caring, tolerant, polylogic: maternal? "...We are dealing with a function that guarantees the subject's entry into a modality, a fragile one to be sure, of the ulterior, unavoidable oedipal destiny, but one that can also be playful and sublimational" (Kristeva 1987: 46). A function that, in so far as it carnivalizes the oedipal necessities, ensures the unfolding of the multiple speeches and existences that the polylogue demands. A function that turns discipline into play. A subtilization of the superego.

\section{Eros and Narcissus}

Two ludic destinies are opened by this discipline. The first one, situated, so to say, under the sign of Eros, of the male libido, is driven by the phantom of an ideal ego, inflated through the narcissistic absorption of the mother. It acquires its impetus from the developments of the oedipal stage. Fascinated by the visual, specular double of the phantasm of a primeval condition, it pursues, from one object to the next one, the trajectory of a centrifugal and metonymic quest for an image that is never adequate, never the "true one." Its outward thrust whose turbulent sublimational dialectic is first problematized by Plato and whose interminable sliding over the fugitive object of desire is perused by Lacan, finds its knowledgable epitome in Don Juan's scepticism and in the principle of the seducer. Ludic and "empty," "unessential," the incessant flight of the seducer unfolds through a multiplication of spaces and through the shattering of identity into masks. The Mallarméan "Nothing 
will have taken place but the place," running like a refrain throughout Kristeva's work, thus seems to recapitulate this movement that offers to the modern soul its utopia of "two plus two makes four": a "polytopia" sustained by mathematics and laughter.

The second movement is situated by Kristeva under the sign of Narcissus, the unheroic youth who died for the love of his image looking at him from the vide of the lost maternal space. Centripetal rather than centrifugal, unfolding through a metaphorical and heterogeneous leap rather than through metonymical sliding, amorous rather than desiring, verbal and musical rather than specular, the narcissistic operation takes us towards the scene of primary identification.

"What is the object for? It serves to give sexual existence to anguish.[...] The object of Narcissus is psychic space; it is representation itself, fantasy"(Kristeva 1987: 116). It is Narcissus's tragic mistake to remain unaware of this truth of the objectlessness of his love. At the crisis of Antiquity Plotinus "corrects" the mistake by reversing Narcissus's love away from the image and towards its source: he thus effects a synthesis between the platonic search for ideal beauty and the autoeroticism of one's proper image. Through an idealizing process that is incorporating rather than sublimating, neoplatonism interiorizes the platonic quest: beauty is incarnated in the inner space creating the light of Occidental internality, of the Occidental "soul."

It is Kristeva's point that we should revisit the fragile and archaic settings of the Narcissus scene. Not in order to repeat the neoplatonic movement towards the luminous closure of a self-love, no longer possible, but in order to gaze once again at the image. Knowledgeably this time, and with a full awareness of its fakeness and its irreality. It is with a view to our lucidity as the creators of images and to our knowledgable love for our own creations that Kristeva evokes, from the Narcissus settings, the figure of the imaginary father. The narcissistic movement towards the imaginary father offers a ludic opening of our destiny, repeating the neoplatonic incorporation, but not its closure, of the polytopic erotic quest. A constellation is thus added to the unfurling of empty spaces; the seducer is internalized into a creator in love with her creations. This gift - the love of our irreal creations, a maternal love par excellence as any reader who ever sympathized with Mary Shelley's Monster knows - may be needed by a future humanity more than we can imagine today. 


\section{Quanta, Protozoa, and Extraterrestrials}

The subtilization of the superego, as problematized by Kristeva via her aionic explorations, relies, therefore, on (1) an attentiveness to the heterogeneity of drives and to their archaic hold on the maternal continent; (2) an explication of the permanent process of stabilization-destabilization in which the symbolic and the semiotic are implicated; (3) an insistence on the multiplicity of modalities of access to the symbolic function; (4) an emphasis on the mechanism of idealization as (feminine?) incorporation rather than sublimation. It is ultimately derivable from the elaboration of a position of symbolicity which arises from primary identification, which launches us immediately into the place of the maternal desire, and which makes possible the emergence of the imaginary father as the promise of a ludic entry into the oedipal exigencies, the promise of a polylogic unfolding of language, of a life quivering on the edge of permanent undecidability.

Does, consequently, the quest for the mother yield a ... father? "A strange father it must be," writes Kristeva in connection with Freud's "father of individual prehistory" that she elaborates into her own concept of the imaginary father. For this father is, of course, also the mother. But then - a strange mother! For this mother-and-father belongs to a modality that is ignorant of gender and, ultimately, it is pointless to ask "who might be the object of primary identification, daddy or mummy" (Kristeva 1987: 28). This uncertainty, requiring as it does its concrete ramifications, can nevertheless be expanded beyond the stage of primary identification. For although phallic idealization begins with "the putting to death of the feminine body" and with the "appropriation of female generative power - a dreaded power," although paternal law emerges as a substitute for and an occultation of the crucial importance of the mother and of the maternal jouissance (Kristeva 1974: 457), it is also a "truth" that the phallus is the mother (Kristeva 1980: 191), and that maternal power replaces and veils the murdered father (Kristeva 1974:547). The occluded generative power as the phallus as the Name of the father as the phallic mother as the dead father inscribe a "quantum" layer in the signifying process, a layer, that is, of uncertainty and complementarity that makes the simultaneous clarity of all parameters impossible but also manifests their alliance. At any moment in the advent of the speaking being or in the functioning of the "city," the maternal and the paternal are always already substitutes 
for one another, "symbols" of one another, present and absent, dead and vibrant with power.

If there is a "superstring" or "texture" of a sorts that might be seen as underlying this fundamental uncertainty, it is a string or texture of nothingness: the death drive. Kristeva asserts that "language, already as a semiotic chora but above all as a symbolic system, is at the service of the death drive" (Kristeva 1984: 70). And even more strongly, "language is the terrain of deathwork" (Kristeva 1983:38) ${ }^{18}$ Language is the "master" that diverts and confines the death drive, yet only through the paradox that makes death produce both life and signification.

Through the death drive's reiteration, that is. Kristeva's postulate points towards Freud's definition of the drive as "inherent inertia" and as the gravitating of life towards the inorganic state that it has been forced to abandon. In Freud, this definition in terms of mechanics finds its biological example in the propagation through scission that preceded sexual reproduction: a myth inviting us back to the primeval suicidal impulse of the protozoan whose splitting initiated the perpetuation of its species and the multiplication of cells that made higher forms of life possible. Later developments have added dramatically to this picture by revealing that the splitting is, indeed, a reproduction of the "memory" of the cell; that the splitting "copies" the "writing" of the genetic code through the redoublings and reversals of the "double helix." The separation, the abyss that opens in the slit is thus both reproductive and signifying: it is this signifying aspect that Kristeva adds to Freud's biological myth. Guided by the same considerations, she adds a paternal inscription to Klein's archaic mother. Kristeva's concept of language as ultimately the work of death thus introduces the problem of signification within the most primal settings: there is, she insists, an archaic inscription of the Third party at the pre-oedipal stage that Melanie Klein, the audacious theoretician of the death drive, elaborates. Hence, for Kristeva, signification itself can be thought of as an echo of the processes of separation in biochemistry: the death drive, regarded by Freud as silent and discernible only in instinctual disorders, is described by Kristeva as "that which speaks" (Kristeva 1974: 611) through incision and repetition. "The division, indeed, the multiplication of matter is thus shown as one of the foundations of the signifying function" (Kristeva 1984: 169).

A vertiginous foundation, to be sure, that is in the a-symbolic and asignifiable infinite nothingness of speculative philosophy: a foundation 
in a cut, a scission, a void, a Heraclitean division without beginning or end. What makes this ultimate hiatus work is its return: the repetition, the reiteration, the multiplicity of rupture. The infinite rhythm of deathwork: Prometheus enchained. En-rhythmed to life. The chora retains its renovating capacity only through this rhythm of splitting and separation. As in the final vision of H.D.'s Helen in Egypt - a vision that makes its strange invocation to Dante's "love that moves the sun and the other stars" - for Kristeva's speaking being,

the seasons revolve around

a pause in the infinite rhythm

of the heart and of heaven.

Kristeva's reference to the world of quanta and nucleic acids - be it as scientific myths - her evocation of a vertiginous world of infinite splitting makes us posit an other of gender. The fundamental instability and uncertainty of the maternal / paternal duality and its ultimate disappearance in the cut of the splitting cell come as a reminder that, besides the problematic gender difference, there is also the problematic difference between gender and non-gender. To posit an other of gender, then, is to posit "stars" or "protozoa" from which we differ in so far as we differ between ourselves.

Hence there is a limit to the concerns of this text, a limit punctured by protozoa and stars. If we have to be precise, it is in the cut of this limit that the text hangs. If the symbolic and its syntax are the occultation of sexual difference, if the signifier functions through the exclusion of woman then language is another way to mark the same limit. Between these two - in the nothingness between the genderless word and the genderless star - our endeavour that has nevertheless to use language and to cast a glance from time to time to the stars, unfolds flanked by Urania, the muse of astronomy, of the Big Bang of the expanding, for ever lost maternal body, of - to paraphrase Joseph Brodsky - "the points of space where we are not," and by Osiris, the mummified phallus of the paternal word. But a living and loving father? A child is said to have been conceived lately by way of a star ray that entered the father through the eye - a new wonder of the world. "There are these other forms of life, artificial ones, that want to come into existence. And they are using me as a vehicle for its reproduction and its implementation. ${ }^{19}$ Is it to the impending cry of this child born, of logic that we haste - to its plea for a body? 
The question is, if the "phallus" has taken, theoretically, the place of the "logos," whatever could be the reality that this shift inverts? This study refers to asymmetrical temporalities and loves which can be subsumed under the categories of "male" and "female" libidos, of love in the shadow of the phallus (as Kristeva has it) and of love in the shadow of the mother (as Woolf's To the Lighthouse enables me to say it). Yet all our loves are already in the shadow of the machine and it is in this shadow that I try to situate my question. Is the rigour of playing sufficient to sustain the metaphysics of the body?

To put it differently, is the whole exertion of writing the body a way of witnessing the body's disappearance? Does the effort to recuperate the mother from mystery into the exigencies of the symbolic, into an imaginary father that envelops and holds - does this effort mark the dawn of an epoch in which motherhood will be no less "fictive" than fatherhood, an epoch whose children will be parented from the realms of the invisible protozoa? Children who, rather than engender the formula - to paraphrase one of Kristeva's titles - will be engendered and embraced by it? Does the toil to en-gender language amount to a plea for the ludic preservation of sexual differences and their troubles in a future that may no longer need them? Does this plea transpose the playful en-gendering into an utmost seriousness concerning the very basis of our sociality? Or is woman's word finally summoned to this end - to convey to language a corporeality that will dissolve on this side in order to be handed over there to cyborgs? If this fantastic need, this fantastic supplication reversing the request of Andersen's Little Mermaid arises at all, that is, and fills the universe with its ghostly shivering. "Give me a body, mother - make me mortal so that I can love!" The Little Mermaid had to struggle for her soul through pain but to this uncanny solicitor we shall say: Read! The rhythm is thy body, the syntax will embrace thee.

\section{Notes}

10 The translation in the main text is confusing: Kristeva does not ask "what the 'I' produces". (RPL 36) but what produces the "I" (see Kristeva 1974: 35).

11 In Kristeva's early work these ideas are connected to the Hegelian and Marxian prehistory of her theory. Hence her references to dialectical logic. Later on she sees her project as a deviation from rationalism (including Freud's), that needs no formal justifications. 
12 The problem with Plato is not as simple as that, as Kristeva's later writing acknowledges. See her essay on Symposium in Tales of Love (1987).

13 In a characteristic non sequitur, Elizabeth Grosz quotes the entire passage from The Revolution in Poetic Language about the traversability of the thetic and fails to make any pertinent inferences: compelled by her own preoccupations and by a penchant to impose a dogged reading of Lacan on Kristeva, she notices neither Kristeva's problematic of scission as negativity and rejection receding in the Heraclitean abyss of matter always already split, nor Kristeva's insistence on the return of scission as operating the semiotic traversing of the thetic, nor, indeed, the fact that this problematic is linked to Kristeva's interest in scars and separations that precede the mirror stage and the thetic.

14 Kristeva returns a number of times to Heidegger's reflection on the Greek title of Prometheus Bound, which might be rendered as "Prometheus enrhythmed." (1977: 14, 160; 1980: 135; see too 1974: 102 for enchainement). The choreographic and musical - rhythmic-enchainement of the defiant titan presents the drama of the semiotic ordering of negativity and rebellion.

15 This Freudian term is rendered in English and French as "identification." Its prehistory in nineteenth-century hermeneutics implies a mystic emotional fusion - or, as Kristeva's gloss has it - "the assimilation of other people's feelings" (1987: 24).

16 See "A Pure Silence: The Perfection of Jeanne Guyon" (Kristeva 1987: 297317).

17 The caution does not apply to women-theorists. It is as if the "danger" arises with artistic practice and the proximity to the "maternal body" that it entails.

18 I cannot discuss here Lacan's writings on the death drive and his own myth of the "lamella," developing Freud's myth of primeaval death-and-reproduction. However, I want to emphasize once more that this archaic node in Kristeva is split into two different configurations of eroticism and destructiveness: female and male libido.

19 The words belong to an artificial life expert (Levy 1992: 120).

\section{Works Cited}

Bollack, Jean and Heinz Wismann. Héraclite ou la séparation. Paris: Minuit, 1972. Butler, Judith. Gender Trouble: Feminism and the Subversion of Identity. New York: Routledge, 1990. 
- Bodies that Matter: On the Discursive Limits of "Sex". New York: Routledge, 1993.

Grosz, Elizabeth. Sexual Subversions: Three French Feminists. Sydney: Allen and Unwin, 1989.

Heidegger, Martin. Nietzsche.Volume II: The Eternal Recurrence of the Same, Trans. by D. F. Krell. San Francisco: Harper and Row, 1984.

Jacobus, Mary. Reading Woman: Essays in Feminist Criticism. New York:

Columbia University Press, 1986.

Kirk, G.S. Heraclitus: The Cosmic Fragments. Cambridge: Cambridge University Press, 1954.

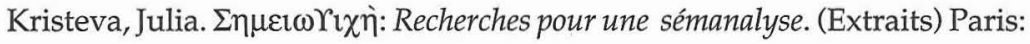
Seuil, 1969.

—. La Révolution du langage poétique: l'avant-garde à la fin du XIXe siècle, Lautréamont et Mallarmé. Paris: Seuil, 1974.

— et al. La Traversée des signes. Paris: Seuil, 1975. Polylogue. Paris: Seuil, 1977.

- Desire in Language: A Semiotic Approach to Literature and Art, trans. by T. Gora, A. Jardine, and L.S. Roudiez. New York: Columbia University Press, 1980.

—. "Oscillation between Power and Denial." New French Feminisms. Eds. E. Marks and I. de Courtivron. 165-167. New York: Schocken Books, 1981.

- Powers of Horror: An Essay on Abjection. Trans. L.S. Roudiez. New York: Columbia University Press, 1982.

-. "Within the Microcosm of 'The Talking Cure." Interpreting Lacan. Eds.

J. H. Smith and W. Kerrigan. New Haven and London: Yale University Press, 1983.

Revolution in Poetic Language. Trans. M. Waller. New York: Columbia University Press, 1984.

- About Chinese Women. Trans. A. Barrows. New York - London: Marion Boyars, 1986.

—. Tales of Love. Trans. L.S. Roudiez. New York: Columbia University Press, 1987.

- Black Sun: Depression and Melancholia. Trans. L.S.Roudiez. New York: Columbia University Press, 1989.

Levy, Steven. Artificial Life: The Quest for a New Creation. New York: Pantheon Books, 1992.

Nikolchina, Miglena. "The lost territory: Parables of exile in Julia Kristeva." Semiotica 86-3/4 (1991): 231-246. 
Julia Kristeva: The Polylogic Wager (Part II) · 93

Oliver, Kelly. Reading Kristeva: Unraveling the Doublebind. Bloomington: Indiana University Press, 1993.

Rajan, Tilottama. "Trans-Positions of Difference: Kristeva and Post-

Structuralism." Manuscript, 1992.

Ricoeur, Paul. Freud and Philosophy: An Essay on Interpretation. New Haven and London: Yale University Press, 1970.

Robinson, T.M. Heraclitus: Fragments. A text and translation with a commetary. Toronto: University of Toronto Press, 1987.

Rose, Jacqueline. Sexuality in the Field of Vision. London: Verso NLB, 1986.

Silverman, Kaja. The Acoustic Mirror: The Female Voice in Psychoanalysis and Film. Bloomington: Indiana University Press, 1988.

Stanton, Domna. "Difference on Trial: A Critique of the Maternal Metaphor in Cixous, Irigaray, and Kristeva." The Poetics of Gender. Eds. C. G. Heilbrun and N. K. Miller. New York: Columbia University Press, 1986. 157-182. 